\title{
Floristic composition and species richness of soil seed bank in three abandoned rice paddies along a seral gradient in Gwangneung Forest Biosphere Reserve, South Korea
}

\author{
Yong-Chan Cho ${ }^{1 *}$ Did, Seon-Mi Lee ${ }^{2}$ and Chang-Seok Lee ${ }^{3}$
}

\begin{abstract}
Background: We sought to understand the relationship between the seed bank and vegetation in abandoned rice paddies in South Korea, in order to guide management of these sites. We investigated the floristic composition and species richness of the soil seed bank and ground vegetation in former paddies along three seral gradients (wet meadow, young forest, and mature forest) in Gwangneung Forest Biosphere Reserve.

Results: Seed bank samples contained 59 species, of which the dominant families were Cyperaceae, Gramineae, and Polygonaceae. Species richness and seedling density (59 taxa and 19,121 germinants from all samples) were high. Carex spp. (11, 921 germinants) were the dominant taxa. The species composition in the seed bank changed gradually as the land transitioned from wet meadow to mature forest. Sørensen's index of similarity between above- and below-ground vegetation was $29.3 \%$ for wet meadow, 10.8\% for young forest, and 2.1\% for mature forest. Germinant density also declined, with 10, 256 germinants for wet meadow, 6445 germinants for young forest, and 2420 germinants for mature forest.

Conclusions: Changes in aboveground environment and life history traits such as amphicarpic plants, likely affect the composition of soil seed bank species. Abandoned paddy fields may be good sites for restoration of wetland forest and conservation of wetland habitat. Some intervention may be required to promote the recovery of a natural species assemblage.
\end{abstract}

Keywords: Biosphere reserve, Rice paddy, Secondary succession, Soil seed bank, Wetland

\section{Background}

In abandoned agricultural fields, the initial vegetation recovery is determined mainly from the composition of the soil seed bank and adjacent vegetation. The contribution of the seed bank to the regeneration process mainly depends on the management history and structural and compositional development of aboveground vegetation. The composition of the seed bank depends on the production and composition of present and previous vegetation,

\footnotetext{
* Correspondence: bz0288@korea.kr

${ }^{1}$ Plant Conservation Division, Korea National Arboretum, Pocheon 11186,

South Korea

Full list of author information is available at the end of the article
}

as well as on the longevity of the seeds under local conditions (López-Mariño et al. 2000). Abandoned rice paddies offer an opportunity to restore wetland vegetation and reestablish traditional landscapes (Lee et al. 2002), helping to maintain endangered wetland species found in the paddy fields that co-existed with rice cultivation (Fujioka et al. 2001; Yamada et al. 2007, 2013). Information regarding the relationship between the soil seed bank and ground vegetation may inform conservation management of newly emerging habitat, such as the use of abandoned paddies to manage important species and improve habitat diversity (Yamada et al. 2013; Hopfensperger 2007), and

(c) The Author(s). 2018 Open Access This article is distributed under the terms of the Creative Commons Attribution 4.0 International License (http://creativecommons.org/licenses/by/4.0/), which permits unrestricted use, distribution, and 
help us understand the resilience of such ecological systems.

The role of soil seed bank to vegetation development following disturbance has been reported by numerous authors (Yamada et al. 2007; Keddy et al. 1989; Looney and Gibson 1995; Falińska 1999; Chambers 2000; Zabinski et al. 2000; Bossuyt and Hermy 2001; Harwell and Havens 2003; Richter and Stromberg 2005; Lang and Halpern 2007; Lee et al. 2008; Li et al. 2008; Ma et al. 2011, 2013; Savadogo et al. 2017) because it often leads the initial vegetation trajectory and species composition in the course of secondary succession after disturbance. Richness and density of soil seed banks often decrease as vegetation passes through the stages of succession (Pickett and McDonnell 1989; Thompson 2000). Lang and Halpern (2007) reported that the effect of the seed bank was masked by the encroachment of conifers. Moreover, Leicht-Young et al. (2009), Looney and Gibson (1995), Ma et al. (2011), and Yang and Li (2013) argued that such decrease of species richness and germinant density in the seed bank does not necessarily happen. In wetland ecosystems, both how seed banks influence the composition of vegetation and how vegetation affects the seed bank in space and time are still not well understood (Hopfensperger 2007).

In recent years, farmers have largely abandoned rice cultivation, mainly due to reduced demand and shrinking profits in eastern Asia, particularly in Japan and South Korea. In South Korea, the top rice-producing country in the world (FAO 2015), the agricultural population decreased gradually from 3.5 million people in 1985 to 1.7 million people in 2005 (Ministry of Agriculture and Forestry 2006), and the area of abandoned paddies was 24,100 ha in 2005 (2.2\% of the total area of paddy fields) (Rhee et al. 2009).

In Asia, secondary succession in abandoned rice paddies has attracted attention from restoration ecologists and practitioners because it may provide a model for wetland restoration (Lee et al. 2002; Byun et al. 2008). The management and conservation of specific weed communities and specialist plants have been studied (Yamada et al. 2007, 2013). If abandoned fields remained wet, they usually developed into wet grasslands (Comín et al. 2001) or wet woodlands dominated by Salix and Alnus species (Lee et al. 2002). Yamada et al. (2002) reported that the number of plant species in the soil seed bank was greatest in the first year of abandonment, but it declined steadily with the process of succession in abandoned rice paddies in Japan. Lee et al. (2008) also reported a decreasing trend for the number of species in soil seed banks along the succession of paddies studied.

In the present study, we evaluated the change in functional species composition in soil seed banks with aboveground vegetation development along a secondary succession gradient in rice paddy fields in South Korea (see Fig. 1). The primary objective was to clarify whether the soil seed bank composition, especially in terms of species' growth form and habitat affinity, changed with succession. We also clarified the relationship between the seed bank and type of aboveground vegetation.

\section{Results \\ Vegetation structure}

There was a significant change in the vegetation structure along the seral gradients (wet meadow as WM, young forest as YF, and mature forest as MF) in our study area (Table 1, Fig. 2). Only a few stems of Salix spp. occurred in WM and their age was less than 5 years. Canopy closure increased as the vegetation matured to forest (from 0\% in WM to $98 \%$ in MF). Mean ages of the canopy trees in the young and mature forests were 20 and 35 years old, respectively. The stem density of woody species peaked in MF, suggesting active recruitment of trees and shrubs such as Salix koreensis and Acer tataricum. Expansion of woody basal area $\left(18.8 \mathrm{~m}^{2} \mathrm{ha}^{-1}\right.$ in YF and $22.6 \mathrm{~m}^{2} \mathrm{ha}^{-1}$ in MF) was concurrent with reduced stem density as the forests matured. The WM stage had only a few juvenile individuals of Salix spp. MF exhibited a multi-layered canopy (composed of Salix and Alnus spp.), a subcanopy (composed of Quercus, Acer, and Fraxinus spp.), and herbaceous vegetation, but YF contained only a simple layered (canopy and ground vegetation) structure.

\section{Seed bank composition}

The seed bank samples contained a total of 19,121 seedlings of 59 taxa (including 3 unidentified taxa of genera Cyperus, Fimbristylis, and Carex). These species belonged to 44 genera of 23 families (Table 2). Cyperaceae accounted for the largest share $(23.9 \%, 14$ species) of the seed bank species, followed by Poaceae $(16.9 \%, 10$ species) and Polygonaceae ( $8.5 \%, 6$ species).

An enormous number of seedlings were germinated from soils. Seedling density decreased along the seral gradient from WM $\left(205,120\right.$ germinants $\left.\mathrm{m}^{-2}\right)$ to YF $(128,900$ germinants $\mathrm{m}^{-2}$ ) and MF (48,400 germinants $\mathrm{m}^{-2}$ ) (Fig. 3).

Graminoids (28 taxa) and forbs (29 taxa) far outnumbered the trees and shrubs (2 taxa). Native species comprised over 94\% (53 species) of the seed bank, and annuals had a larger share $(71 \%, 40$ species) than perennials (29\%, 16 species). Wetland species comprised approximately $55 \%$ (31 species) of all seedlings. In the whole seed bank, approximately $41 \%$ (23 species) of the seedlings were classified as ruderal species, while less than $4 \%$ ( 2 taxa) were shade-tolerant forest species.

\section{Seed bank dynamics}

While seedling density and species richness of annual, perennial, wetland, ruderal, graminoid, and forb species 


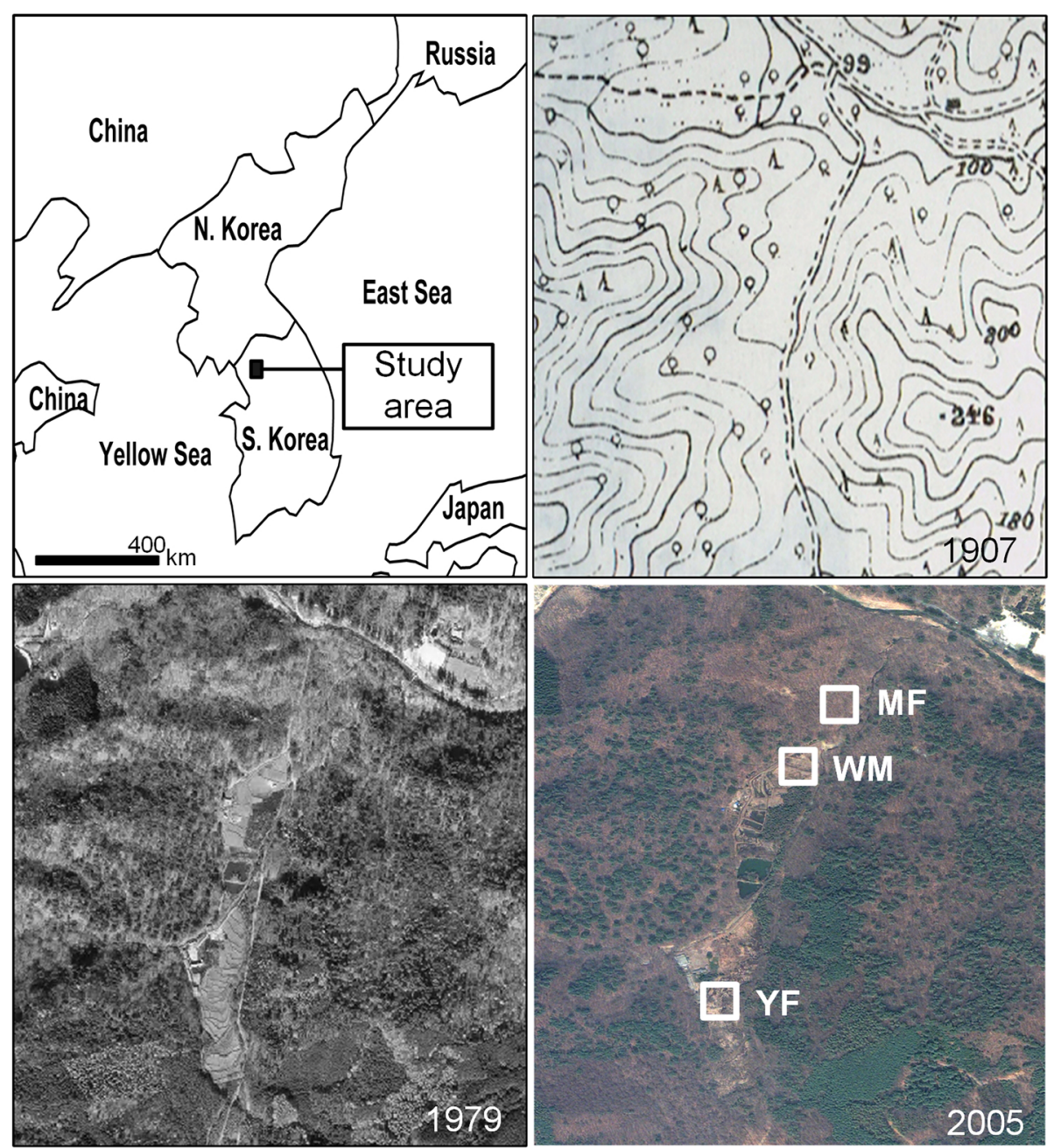

Fig. 1 Location (upper left), a topographic map constructed in 1907 (upper right), the aerial photographs taken in October 1979 (lower left), and the satellite image (Quickbird) taken in April 2005 (lower right) of the study area. Three sample sites (WM-wet meadow, YF—young forest, and MF-mature forest) were established in a successional gradient

declined from WM to MF, the opposite was true for trees and shrubs (Fig. 4). Figure 5 shows a trajectory of changes in species composition of the seed banks from WM to MF, based on NMS. The plots of MF show a tighter cluster, indicating that the types of vegetation were much more similar to each other than in YF and WM. YF appeared to diverge from WM and converge into MF vegetation, as indicated by the arrow in Fig. 5 .

The germinant density of perennial species (Oenanthe javanica, Carex neurocarpa, and Pimpinella brachycarpa) with higher species scores (based on NMS results) decreased from the right to the left, as opposed to annuals (Pilea mongolica, Persicaria conspicua, and Bidens frondosa) on the NMS Axis I.

The MRPP results agreed with our interpretation of NMS. Both overall $(A=0.1349, p \leq 0.0001)$ and pairwise tests revealed significant differences in the composition of seed bank species among the three successional stages. Species composition was most different between WM and MF $(A=0.1536, p<0.0001)$, least different between WM and YF $(A=0.0333, p=$ $0.0021)$, and intermediate between YF and $\operatorname{MF}(A=$ $0.1218, p<0.0001)$. Our ISPAN listed 29 species as indicators of the three successional stages (Table 3 ). A majority of species (23 species) were identified as open WM indicators, 4 species were YF indicators, and 2 species were MF indicators.

\section{Similarity in seed bank and vegetation}

Generally, as shown in Table 2, seedling density and species richness in the seed bank did not correspond to those of the ground vegetation except in the case of a few species. For example, no seedling of Juncus effusus emerged from the seed bank, but it was a common species in WM. In addition, despite its high seedling density in the WM seed bank, Hypericum 
Table 1 Canopy closure and vegetation structure of wet meadow (WM), young forest (YF), and mature forest (MF) in abandoned rice paddies

\begin{tabular}{llll}
\hline Structural variable & WM & YF & MF \\
& Mean \pm SE & Mean \pm SE & Mean \pm SE \\
\hline Canopy closure (\%) & - & $73 \pm 4$ & $98 \pm 2$ \\
Stem density (stems ha ${ }^{-1}$ ) & & \\
Quercus aliena & - & - & $60 \pm 27$ \\
Q. serrata & - & - & $60 \pm 43$ \\
Salix spp. & - & $1280 \pm 146$ & $180 \pm 38$ \\
Alnus japonica & - & $213+32$ & $80 \pm 36$ \\
Acer tataricum & - & $827 \pm 65$ & $360 \pm 73$ \\
Others & - & $107 \pm 19$ & $2170 \pm 703$ \\
Total & - & $3387+114$ & $2760 \pm 703$ \\
Basal area (m ${ }^{2}$ ha & & & \\
Quercus aliena & - & & $6.2 \pm 0.4$ \\
Q. serrata & - & - & $2.1 \pm 1.9$ \\
Salix spp. & - & - & $8.5 \pm 2.9$ \\
Alnus japonica & - & $8.0 \pm 2.5$ & $2.2 \pm 1.0$ \\
Acer tataricum & - & $3.4 \pm 1.6$ & $4.7+1.0$ \\
Others & - & $18.8+3.1$ & $2.6 \pm 2.8$ \\
Total & - & & \\
\hline
\end{tabular}

laxum occurred only in YF. Meanwhile, Aneilema keisak and Persicaria thunbergii were common in both seed bank and ground vegetation. Overall, WM showed the highest Sørensen's index (29.3\%), followed by YF (10.8\%) and MF (2.1\%).

\section{Discussion}

\section{Floristic composition of soil seed bank}

Life history and seed size were closely correlated with seed bank formation in the rice paddies. Cyperus hakonensis (graminoid), Rotala pusilla (forb), Rotala indica (forb), and Lindernia procumbens (forb) all revealed explosive emergent density. These annuals are early seral species with prolific seed production and small seed size, which make them well adapted to the wet conditions of rice fields, and rice paddies and artificial levees in paddies are major habitat for them (Ryang et al. 2004). Thus, paddy plant species (Yamada et al. 2007) that are adapted to cultivation activities such as herbicide application, tillage, and plowing contributed to the composition of the soil seed bank before the rice paddies were abandoned.

Annuals (mainly graminoids and open wetland species) with high germinant density and richness characterized the soil seed bank of the abandoned paddies. The change in aboveground vegetation from open meadow to forest with decreasing canopy openness also affect the establishment of and seed supply from early successional wetland species (van der Valk 1981). Higher abundance of annual plants as pioneer species may indicate their long persistence in the seed bank and their role in spontaneous succession in newly abandoned paddies.

As a representative paddy weed, Alopecurus aequalis tends to have long-term persistent seed banks, exhibiting a slow decline in seed abundance over time (Yamada et al. 2013). In our samples, however, A. aequalis appeared only in the early seral stage (WM). The relatively longer time span of later seral stages (more than 20 years since

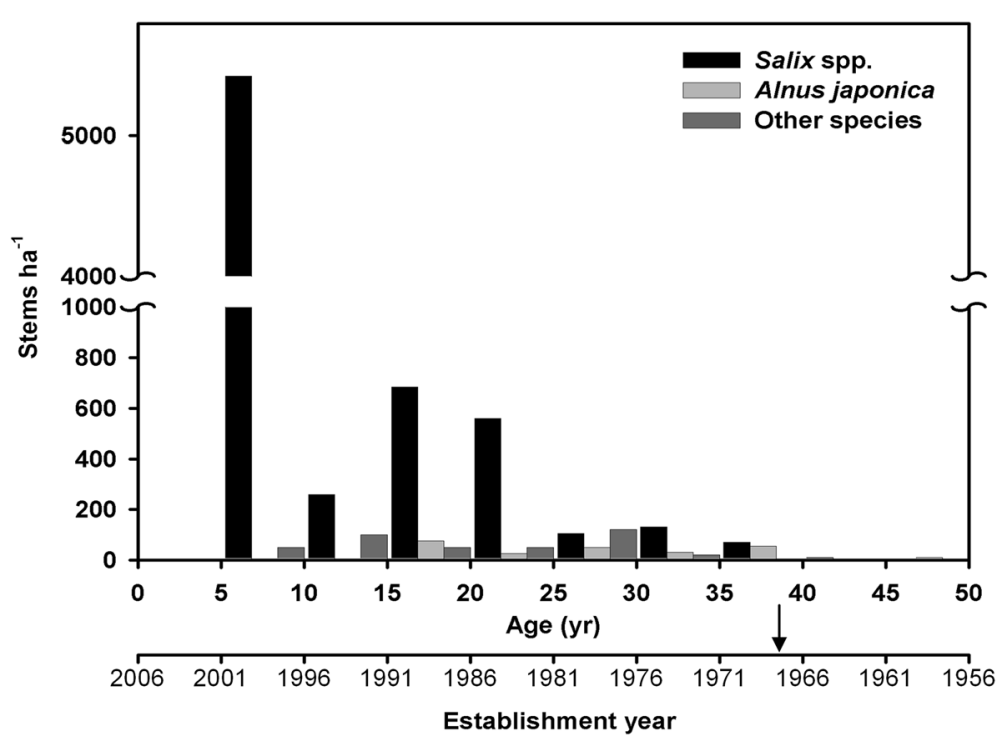

Fig. 2 Composition of woody species (heights $\geq 2 \mathrm{~m} ; n=183$ ) in a chronosequence of the study area. Arrow in diagram indicates inundation year (1968) 
Table 2 Frequency (\% of subplots) and abundance (mean cover or total germinant density) of species in ground vegetation and soil seed bank among seral stages. Differences in vegetation cover were omitted

\begin{tabular}{|c|c|c|c|c|c|c|c|c|c|c|c|c|}
\hline \multirow[t]{3}{*}{ Species } & \multicolumn{6}{|c|}{ Ground vegetation } & \multicolumn{6}{|c|}{ Seed bank } \\
\hline & \multicolumn{3}{|c|}{ Frequency (\%) } & \multicolumn{3}{|c|}{ Cover (\%) } & \multicolumn{3}{|c|}{ Frequency (\%) } & \multicolumn{3}{|c|}{ Density (stems $\mathrm{m}^{-2}$ ) } \\
\hline & $\overline{W M}$ & YF & MF & WM & YF & MF & $\overline{W M}$ & $\mathrm{YF}$ & MF & WM & YF & MF \\
\hline \multicolumn{13}{|l|}{ Graminoids } \\
\hline Alopecurus aequalis & & & & & & & 32 & & & 2180 & & \\
\hline Carex aphanolepis & & 70 & 50 & & 23 & 13 & & & & & & \\
\hline C. glabrescens & & & & 0 & & & & & & & & \\
\hline C. neurocarpa & & & & & & & & & 4 & & & 20 \\
\hline Carex sp. & & 10 & 20 & & $<1$ & 2 & 100 & 100 & 100 & 77,340 & 110,560 & 48,660 \\
\hline Cyperus amuricus & & & & & & & 16 & & 20 & 220 & & 100 \\
\hline Cyperus difformis & 10 & & & $<1$ & & & 88 & 20 & 12 & 4960 & 160 & 220 \\
\hline Cyperus hakonensis & & & & & & & 100 & 84 & 36 & 23,440 & 8120 & 400 \\
\hline Cyperus iria & & & & & & & 28 & 4 & 52 & 300 & 20 & 1540 \\
\hline Cyperus nipponicus & & & & & & & 4 & & 8 & 20 & & 40 \\
\hline Cyperus sanguinolentus & & & & & & & 28 & & & 340 & & \\
\hline Cyperus sp. & & & & & & & & 4 & & & 20 & \\
\hline Digitaria ciliaris & & & & & & & 32 & 12 & & 180 & 20 & \\
\hline Echinochloa crusgalli & & & & & & & 16 & 4 & 4 & 80 & 20 & 20 \\
\hline Echinochloa sp. & & & & 3 & & & & & & & & \\
\hline Eleocharis congesta & & & & & & & 96 & 56 & 4 & 8440 & 3740 & 20 \\
\hline Eleusine indica & & & & & & & & & 8 & & & 40 \\
\hline Eragrostis multicaulis & & 10 & & & 1 & & 48 & 40 & 16 & 980 & 1280 & 120 \\
\hline Eriocaulon hondoense & & & & & & & 4 & 4 & & 40 & 20 & \\
\hline Fimbristylis dichotoma & & & & & & & 44 & 24 & & 2038 & 1274 & \\
\hline Fimbristylis sp. & & & & & & & & 4 & 4 & & 51 & 51 \\
\hline Glyceria leptolepis & & 40 & & & 12 & & & & & & & \\
\hline Juncus alatus & & & & & & & 32 & 84 & 28 & 700 & 10,580 & 940 \\
\hline J. effusus & 100 & 20 & & 25 & 1 & & & & & & & \\
\hline J. leschenaultii & & & & & & & 60 & 12 & & 7040 & 60 & \\
\hline J. tenuis & & & & & & & & & 4 & & & 20 \\
\hline Kyllinga brevifolia & & & & & & & 56 & 48 & 8 & 1340 & 980 & 40 \\
\hline Leersia japonica & & 20 & & & 2 & & & & & & & \\
\hline Lipocarpha microcephala & & & & & & & 24 & 16 & 4 & 1080 & 100 & 20 \\
\hline Microstegium vimineum & 30 & 90 & 20 & 2 & 9 & 1 & 24 & & & 280 & & \\
\hline Miscanthus sp. & & 10 & & & 1 & & & & & & & \\
\hline Oplismenus undulatifolius & & 20 & 70 & & 1 & 8 & & & & & & \\
\hline Panicum dichotomiflorum & & & & & & & & 4 & & & 20 & \\
\hline Phalaris arundinacea & 10 & & & $<1$ & & & & & & & & \\
\hline Sacciolepis indica & & & & & & & 8 & & & 140 & & \\
\hline S. indica & & & & & & & 4 & & & 40 & & \\
\hline Scirpus karuizawensis & & 20 & & & 1 & & & & & & & \\
\hline Scirpus komarovii & 10 & & & $<1$ & & & & & & & & \\
\hline Setaria viridis & & & & & & & 8 & & 4 & 80 & & 20 \\
\hline
\end{tabular}


Table 2 Frequency (\% of subplots) and abundance (mean cover or total germinant density) of species in ground vegetation and soil seed bank among seral stages. Differences in vegetation cover were omitted (Continued)

\begin{tabular}{|c|c|c|c|c|c|c|c|c|c|c|c|c|}
\hline \multirow[t]{3}{*}{ Species } & \multicolumn{6}{|c|}{ Ground vegetation } & \multicolumn{6}{|c|}{ Seed bank } \\
\hline & \multicolumn{3}{|c|}{ Frequency (\%) } & \multicolumn{3}{|c|}{ Cover (\%) } & \multicolumn{3}{|c|}{ Frequency (\%) } & \multicolumn{3}{|c|}{ Density (stems $\mathrm{m}^{-2}$ ) } \\
\hline & WM & YF & MF & WM & YF & MF & WM & YF & MF & WM & YF & MF \\
\hline \multicolumn{13}{|l|}{ Forbs } \\
\hline Aeschynomene indica & 20 & & & $<1$ & & & 4 & & & 20 & & \\
\hline Aneilema keisak & 50 & & & 1 & & & 52 & & & 880 & & \\
\hline Angelica decursiva & & & 70 & & & 7 & & & & & & \\
\hline Artemisia sp. & & 10 & & & 1 & & & & & & & \\
\hline Astilbe rubra & & 10 & & & 1 & & & & & & & \\
\hline Athyrium yokoscense & & & 10 & & & $<1$ & & & & & & \\
\hline Bidens frondosa & 40 & & & 2 & & & 4 & & & 60 & & \\
\hline Cardamine flexuosa & & & & & & & 8 & 8 & & 60 & 40 & \\
\hline Centipeda minima & & & & & & & 80 & 32 & 8 & 2200 & 540 & 60 \\
\hline Chrysosplenium & & & 40 & & & 4 & & & & & & \\
\hline Clinopodium chinense & & 20 & & & 1 & & & & & & & \\
\hline Commelina communis & & 10 & & & $<1$ & & & & & & & \\
\hline Corydalis ochotensis & & & 10 & & & $<1$ & & & & & & \\
\hline Desmodium podocarpum & & & 10 & & & $<1$ & & & & & & \\
\hline Disporum smilacinum & & & 40 & & & 4 & & & & & & \\
\hline Dopatrium junceum & & & & & & & 64 & 64 & & 2200 & 2560 & \\
\hline Dryopteris tokyoensis & & & 10 & & & $<1$ & & & & & & \\
\hline Duchesnea indica & & 10 & 10 & & $<1$ & $<1$ & & & & & & \\
\hline Equisetum arvense & & 10 & 10 & & $<1$ & $<1$ & & & & & & \\
\hline Euphorbia supina & & & & & & & 4 & & & 20 & & \\
\hline Geranium sp. & & & 10 & & & $<1$ & & & & & & \\
\hline Glycine soja & 90 & 50 & 30 & 7 & 3 & 1 & 8 & 4 & & 40 & 20 & \\
\hline Hypericum laxum & 30 & & & 1 & & & 92 & 48 & 4 & 8480 & 940 & 260 \\
\hline Impatiens textori & & 20 & 20 & & 1 & 1 & & & & & & \\
\hline Kummerowia striata & 10 & & & $<1$ & & & 28 & & & 400 & & \\
\hline Lindernia procumbens & & & & & & & 100 & 96 & 36 & 13,420 & 12,780 & 340 \\
\hline Liparis krameri & & & 20 & & & 1 & & & & & & \\
\hline Liriope spicata & & & 20 & & & 2 & & & & & & \\
\hline Ludwigia prostrata & & & & & & & 84 & 8 & & 7160 & 40 & \\
\hline Mazus pumilus & & & & & & & 20 & 12 & & 200 & 120 & \\
\hline Meehania urticifolia & & & 80 & & & 13 & & & & & & \\
\hline Monochoria vaginalis & & & & & & & 24 & & & 540 & & \\
\hline Mosla dianthera & 60 & & 10 & 4 & & $<1$ & & & & & & \\
\hline Oenanthe javanica & 50 & & & 10 & & & & 4 & & & 20 & \\
\hline Penthorum chinense & 20 & & & 1 & & & & & & & & \\
\hline Persicaria conspicua & & & & & & & 8 & & & 100 & & \\
\hline P. sagittata & 40 & 50 & & 3 & 2 & & 40 & & & 460 & & \\
\hline P. thunbergii & 100 & 100 & 80 & 28 & 37 & 26 & 36 & 96 & 24 & 440 & 4380 & 300 \\
\hline P. trigonocarpa & & & & & & & 40 & & & 320 & & \\
\hline
\end{tabular}


Table 2 Frequency (\% of subplots) and abundance (mean cover or total germinant density) of species in ground vegetation and soil seed bank among seral stages. Differences in vegetation cover were omitted (Continued)

\begin{tabular}{|c|c|c|c|c|c|c|c|c|c|c|c|c|}
\hline \multirow[t]{3}{*}{ Species } & \multicolumn{6}{|c|}{ Ground vegetation } & \multicolumn{6}{|c|}{ Seed bank } \\
\hline & \multicolumn{3}{|c|}{ Frequency (\%) } & \multicolumn{3}{|c|}{ Cover (\%) } & \multicolumn{3}{|c|}{ Frequency (\%) } & \multicolumn{3}{|c|}{ Density (stems $\mathrm{m}^{-2}$ ) } \\
\hline & WM & YF & MF & WM & YF & MF & WM & YF & MF & WM & YF & MF \\
\hline Phryma leptostachya & & & 10 & & & $<1$ & & & & & & \\
\hline Phyllanthus ussuriensis & & & & & & & 4 & & & 20 & & \\
\hline Pilea mongolica & 70 & 70 & & 8 & 2 & & 4 & & & 20 & & \\
\hline Pimpinella brachycarpa & & & & & & & & & 4 & & & 20 \\
\hline Portulaca oleracea & & & & & & & & 8 & 8 & & 80 & 40 \\
\hline Ranunculus sceleratus & 10 & & & $<1$ & & & & & & & & \\
\hline Rotala indica & & & & & & & 96 & 76 & 4 & 23,320 & 2160 & 20 \\
\hline R. pusilla & & & & & & & 80 & 76 & & 32,820 & 7740 & \\
\hline Rubia akane & & 10 & & & $<1$ & & & & & & & \\
\hline Rumex crispus & & & & & & & & & 16 & & & 100 \\
\hline Sagittaria pygmaea & & & & & & & 32 & & & 1300 & & \\
\hline Sigesbeckia glabrescens & & 20 & & & 1 & & & & & & & \\
\hline Stellaria alsine & & & & & & & 4 & & & 60 & & \\
\hline Vigna angularis & 10 & & & $<1$ & & & & & & & & \\
\hline Viola acuminata & & & 10 & & & $<1$ & & & & & & \\
\hline$V$. verecunda & & 20 & 20 & & 1 & 1 & 4 & & & 20 & & \\
\hline \multicolumn{13}{|l|}{ Trees } \\
\hline Acer tataricum & & & & & & & & 4 & & & 20 & \\
\hline Salix chaenomeloides & 10 & & & $<1$ & & & & & & & & \\
\hline Salix koreensis & 60 & & & 3 & & & 44 & 88 & & 420 & 1520 & \\
\hline \multicolumn{13}{|l|}{ Shrubs } \\
\hline Euonymus alatus & & & 10 & & & $<1$ & & & & & & \\
\hline Ligustrum obtusifolium & & & 20 & & & 1 & & & & & & \\
\hline \multicolumn{13}{|l|}{ Vines } \\
\hline Akebia quinata & & & 70 & & & 9 & & & & & & \\
\hline Clematis apiifolia & & 20 & 50 & & 1 & 4 & & & & & & \\
\hline Smilax china & & & 20 & & & 1 & & & & & & \\
\hline
\end{tabular}

abandonment) could be a reason for the absence of $A$. aequalis in the soil seed bank. The change in aboveground environments from the rice paddy, in terms of canopy closure and multiple layers of vegetation, may be another explanation.

In our samples, interestingly, there were no seedlings of $J$. effusus in the seed bank, although J. effusus is known to be an important species in the soil seed bank in rice paddies (Yamada et al. 2013) and wetlands (Thompson and Grime 1979; Yoon et al. 2011). J. effusus in ground vegetation exhibited high frequency $(100 \%)$ in WM and decreased to 20\% in YF. Moore and Burr (1948) reported that seeds of J. effusus may remain dormant and viable for up to 60 years. The germination rate of J. effusus varied a great deal (from 10 to 98\%) with abiotic factors (light, nutrients, and temperature) (Richards and Clapham 1941) and biotic variables (competition or shading) (Moore and Burr 1948). It is possible that sampled seeds of $J$. effusus simply exhibited a germination rate of 0 . Another explanation is that viable seeds of J. effusus, which has small seeds, were present in deeper soil than we sampled, so they were not included in our samples. In addition, the lack of periodic disturbances can affect some species' reproductive strategy (De Andrade and Miranda 2014). Perennial graminoid such as J. effusus may be expanded using vegetative means in abandoned paddy fields, when disturbance is low, rather than through sexual reproduction with viable seeds.

Although its presence in ground vegetation was very limited, genus Cyperus, including C. hakonensis and C. difformis, revealed explosive germination density in WM and decreasing frequency and abundance of seed 


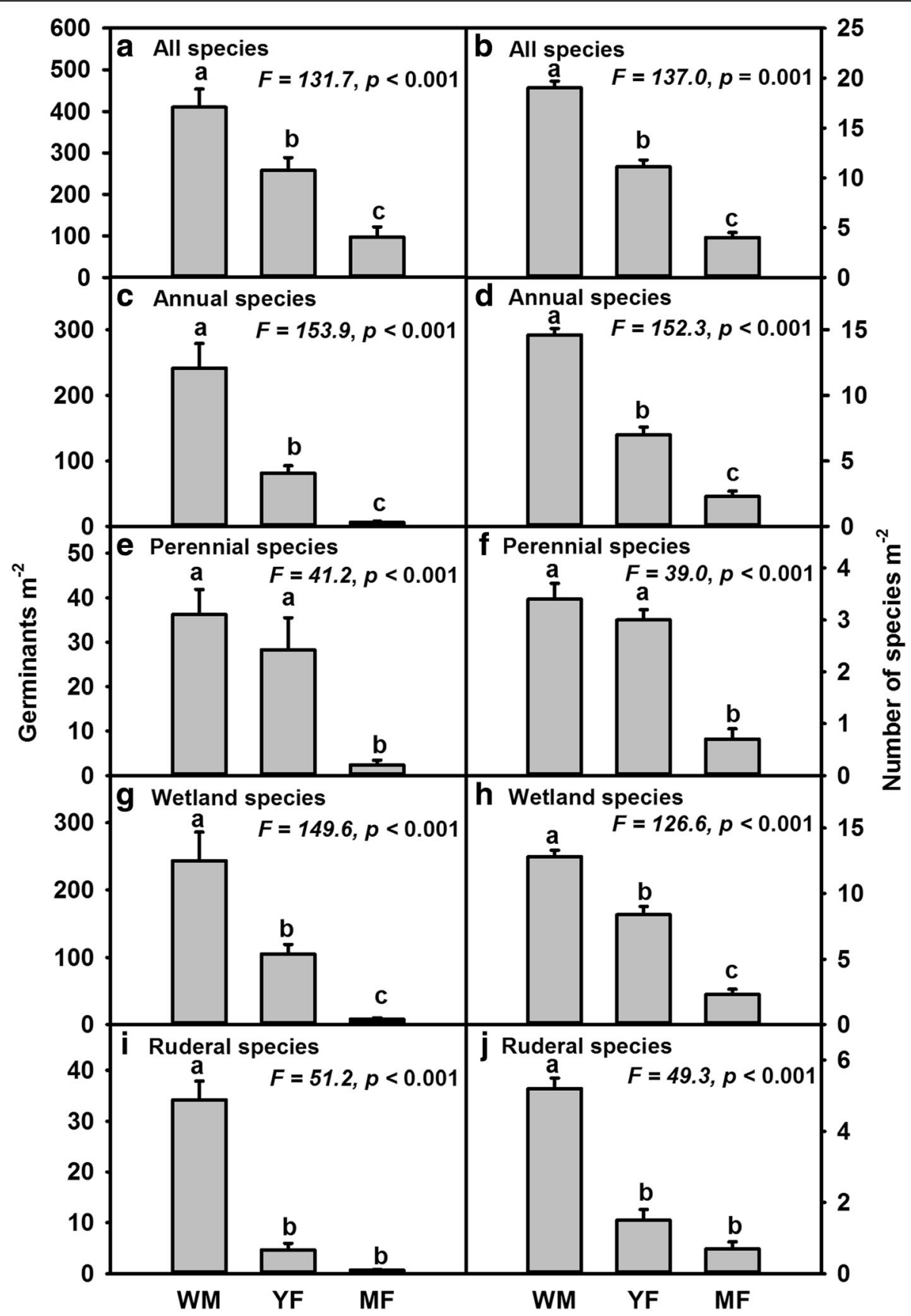

Fig. 3 a-j Comparison (one-way ANOVA) of mean seedling density and species richness of seed bank in wet meadow (WF), young forest (YF), and mature forest (MF), sorted by life history forms. Letters on the tops of bars signify statistically significant difference at $a=0.05$ in Tukey-Kramer test

germination with seral gradient. Those characteristics of Cyperus suggest long-term seed persistence of the species in wetland environments and a gradual decline in successional time and space, even as it shows very low abundance in the ground vegetation of abandoned paddy fields. C. difformis is an important rice paddy plant in Japan (Yamada et al. 2013).

Members of genus Persicaria, including P. sagittata and $P$. thunbergii, were important in the soil seed bank and aboveground vegetation in the three abandoned paddies. $P$. sagittata and $P$. thunbergii were representative annual forb species that are abundant in wetland and riparian ecosystems across South Korea. An annual amphicarpic plant, P. thunbergii, shows relatively stable aerial and subterranean seed allocation and number of seeds per unit of biomass, even in unfavorable conditions (Kim et al. 2016). Those life history characteristics of $P$. thunbergii 


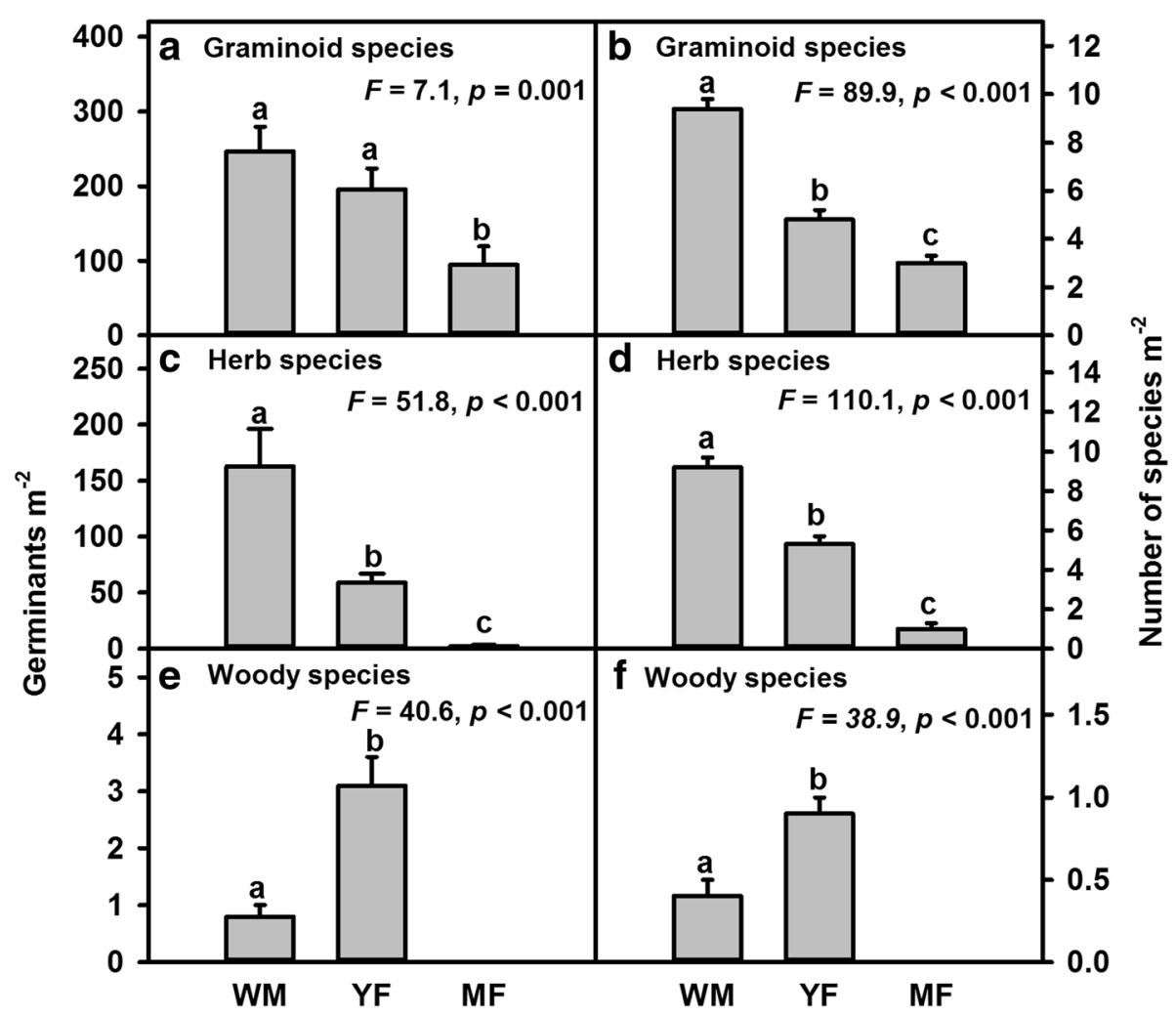

Fig. 4 a-f Comparison (one-way ANOVA) of mean seedling density and species richness of seed bank in wet meadow (WF), young forest (YF), and mature forest (MF), sorted by growth forms. Letters on the tops of bars signify statistically significant difference at $a=0.05$ in Tukey-Kramer test

could explain its sustained presence in the seed bank across various successional stages.

Late successional species, such as trees and shrubs, had a minimal presence in the seed bank, which included only two forest species (Acer tataricum, a tall shrub, and Pimpinella brachycarpa, a forest understory species) in addition to Salix koreensis, a tree closely associated with YF. This result agrees with previous research (Bossuyt and Hermy 2001; Halpern et al. 1999; Olano et al. 2002) which reported few viable seeds in forest soils. The plants in later successional stages, including perennial species (e.g., Meehania urticifolia), shrubs (e.g., Ligustrum obtusifolium), and trees (e.g., Q. aliena, Q. serrata, Cornus controversa), produce relatively larger seeds. The litter layer may hold these seeds and delay their migration down into the soil layer (Chambers JC and JA 1994).

\section{Successional changes in seed bank}

Our results matched well with compositional convergence and a decreasing pattern of density and richness of the soil seed bank along seral stages. Compositional diversity in the seed bank diminished with increasing stand age, possibly due to a gradual loss of species from the seed bank and limited input from late seral vegetation (Plue et al. 2010). Decreased light availability due to tree growth and consequent canopy closure may discourage germination and seed replenishment from light-dependent variable early seral paddy plants in the seed bank.

Litter accumulation during succession may also constrain seed bank composition by affecting litter layer quality and establishment of late seral plants (Schmidt et al. 2009). Closed-canopy forests with multiple layers of vegetation are less favorable to germination and survival of open wet meadow species. Hence, annual wetland plants make a limited contribution to the ground vegetation and seed bank in the YF and MF stages. In turn, the seed bank in abandoned paddies contains few late successional plants and is mainly composed of early successional plants.

\section{Implications for management of paddy fields}

In abandoned paddy fields, species abundance and diversity in seed banks were higher in the early stages of succession and tended to decrease along successional stages. Prach (2003) argued that "spontaneous succession" of native vegetation can be achieved from emergence of the seed bank. This enables "passive restoration" of natural habitat in our study area (Lee et al. 2002). We project that 


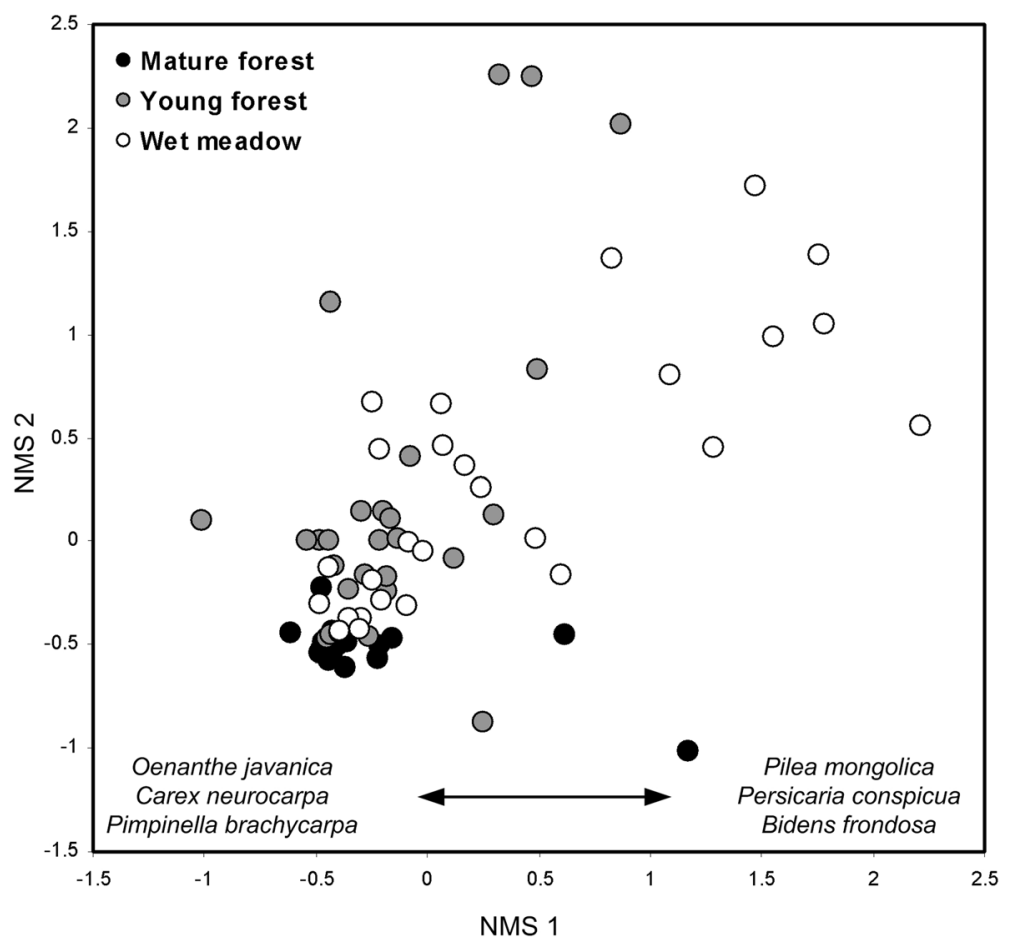

Fig. 5 Non-metric multidimensional scaling (NMS) ordination for species composition of seed bank in a successional gradient. NMS 1 and 2 explained, respectively, 73.6 and $19.8 \%$ of the variation (minimized final stress, $12.5 \%$; final instability 0.0038 )

the rice paddies will eventually become a riparian forest, as suggested by the presence of $S$. koreensis in the seed bank and ground vegetation. Similarity between the seed bank and aboveground vegetation decreased as succession advanced, indicating the minor role played by the seed bank in wetland forest. In addition, the annuals and ruderals from the seed bank may compete with the seedlings of target wetland trees such Salix spp., Alnus japonica, and $Q$. aliena. In conclusion, the greater role played by open meadow plants in the soil seed bank in abandoned paddies suggested that partial and periodic removal of annuals and ruderals and active introduction of woody species as target species may be required for appropriate wetland forest restoration.

In addition to providing territory for forest restoration, abandoned paddy fields can serve as artificial wetland habitat. Wetlands were formerly considered wastelands, and they have consistently been converted into agricultural fields in South Korea (Kim 2017). Wetland habitats that developed from abandoned rice paddies move through various seral stages, such as grassland, shrub land, and forest. The dominant vegetation types in South Korea are secondary and plantation forests. Most low-height vegetation, including grasses and shrubs, in lowlands transitioned to forest vegetation over time (Cho et al. 2016); thus, utilization of abandoned agricultural fields as managed and cultivated habitat has been strongly encouraged in Japan and South Korea recently (Kurechi 2007). Our results showed that the floristic composition of soil seed banks in abandoned rice paddies revealed important roles for spontaneous and rapid development of secondary habitats. Emerging secondary wetland in abandoned fields can be managed as conservation habitat for annual or perennial plant species that are adapted to historical cultivation activities and prefer early successional environments (Yamada et al. 2013). In such cases, historical management guidelines and continuous human intervention are essential to maintaining low-height vegetation and creating early successional environments.

\section{Conclusions}

We investigated the floristic composition and species richness of the soil seed bank and ground vegetation in former paddies along three seral gradients (wet meadow, young forest, and mature forest) in Gwangneung Forest Biosphere Reserve. Our study revealed that species composition of soil seed bank in abandoned rice paddies in Gwangneung Forest Biosphere Reserve was related to changes in aboveground environment by successional development and life history traits such as amphicarpic plants. Abandoned paddy fields may be good sites for restoration of wetland habitat. 
Table 3 Seed bank species showed significant ( $p \leq 0.05$ ) associations with successional stages based on indicator species analysis (ISPAN)

\begin{tabular}{|c|c|c|c|c|}
\hline Species & Seral stage & $I V_{\max }$ & p & Habitat affinity \\
\hline Rotala indica & Wet meadow & 87.6 & 0.001 & Wetland \\
\hline Ludwigia prostrata & Wet meadow & 83.5 & 0.001 & Wetland \\
\hline Cyperus difformis & Wet meadow & 81.7 & 0.001 & Wetland \\
\hline Hypericum laxum & Wet meadow & 79.9 & 0.001 & Wetland \\
\hline Cyperus hakonensis & Wet meadow & 72.2 & 0.001 & Wetland \\
\hline Eleocharis congesta & Wet meadow & 65.0 & 0.001 & Wetland \\
\hline Rotala pusilla & Wet meadow & 61.9 & 0.001 & Wetland \\
\hline Juncus leschenaultii & Wet meadow & 59.4 & 0.001 & Wetland \\
\hline Centipeda minima & Wet meadow & 58.8 & 0.001 & Wetland \\
\hline Aneilema keisak & Wet meadow & 52.0 & 0.001 & Wetland \\
\hline Lindernia procumbens & Wet meadow & 51.3 & 0.003 & Wetland \\
\hline Persicaria trigonocarpa & Wet meadow & 40.0 & 0.001 & Wetland \\
\hline Persicaria sagittata & Wet meadow & 40.0 & 0.001 & Wetland \\
\hline Alopecurus aequalis & Wet meadow & 32.0 & 0.001 & Wetland \\
\hline Sagittaria pygmaea & Wet meadow & 32.0 & 0.002 & Wetland \\
\hline Kyllinga brevifolia & Wet meadow & 31.8 & 0.034 & Wetland \\
\hline Cyperus amuricus & Wet meadow & 28.0 & 0.001 & Wetland \\
\hline Kummerowia striata & Wet meadow & 28.0 & 0.002 & Ruderal \\
\hline Fimbristylis dichotoma & Wet meadow & 27.1 & 0.015 & Wetland \\
\hline Digitaria ciliaris & Wet meadow & 25.6 & 0.006 & Ruderal \\
\hline Monochoria vaginalis & Wet meadow & 24.0 & 0.005 & Wetland \\
\hline Microstegium vimineum & Wet meadow & 24.0 & 0.007 & Wetland \\
\hline Lipocarpha microcephala & Wet meadow & 21.6 & 0.044 & Wetland \\
\hline Persicaria thunbergii & Young forest & 81.1 & 0.001 & Wetland \\
\hline Juncus alatus & Young forest & 73.8 & 0.001 & Wetland \\
\hline Salix koreensis & Young forest & 68.9 & 0.001 & Wetland \\
\hline Dopatrium junceum & Young forest & 38.8 & 0.003 & Wetland \\
\hline Cyperus iria & Mature forest & 43.1 & 0.002 & Wetland \\
\hline Rumex crispus & Mature forest & 16.0 & 0.034 & Wetland \\
\hline
\end{tabular}

$I \mathrm{~V}_{\max }$ refers to maximum observed indicator value. $p$ is the proportion of randomized trials with indicator value equal to or exceeding the observed indicator value

\section{Methods}

\section{Study area}

The study area was located in the Gwangneung Forest Biosphere Reserve (hereafter GFBR; 37 42' 36" $-47^{\prime}$ $41^{\prime \prime} \mathrm{N}$ and $127^{\circ} 8^{\prime} 20^{\prime \prime}-11^{\prime} 58^{\prime \prime} \mathrm{E}$ ) in the northeastern outskirts of Seoul, South Korea (Fig. 1). The GFBR vegetation is classified as cool-temperate broadleaved forest (Lim et al. 2003). The low and riparian types of vegetation adjacent to our study area support higher mean plant species richness (41 species $400 \mathrm{~m}^{-2}$ ) and diversity $\left(H^{\prime}=3.4\right)$ than the upland vegetation (24 species $400 \mathrm{~m}^{-2}$ and $H^{\prime}=1.56$ ) (Cho et al. 2007). Mean annual precipitation and temperature were $141.8 \mathrm{~cm}$ and $11.7^{\circ}$
C, respectively (Korea National Arboretum, internal data file in 2016). The bedrock and soil type are classified as granitic gneiss and fluvial soil, respectively (Cho et al. 2007). The riparian wetlands in the GRBR were converted to rice paddies around 1955 (after the Korean War), and cultivation continued for several decades. Some rice paddies were abandoned after a major flooding in 1968. These abandoned paddies have since become a mature forest (MF in Fig. 1). Some of the remaining paddies were abandoned in the early 1980s and have become young forest (YF in Fig. 1), colonized by tree and shrub seedlings and saplings. Some paddies were abandoned in the early 2000s and have become wet meadow (WM in Fig. 1). The forest vegetation is dominated by willows (Salix koreensis, Salix chaenomeloides) and several hardwood species (Quercus aliena, Quercus serrata, and Alnus japonica). The vegetation of wet meadows consists of graminoids and herbaceous plants such as Juncus effusus, Microstegium vimineum, Persicaria thunbergii, and Glycine soja. Soil organic matter $(3.0 \pm 0.4$ in WM, $4.3 \pm 1.5 \%$ in YF, and $4.4 \pm 0.9 \%$ in MF) and total nitrogen $(0.17 \pm 0.03$ in WM, $0.24 \pm 0.09 \%$ in $\mathrm{YF}$, and $0.26 \pm 0.05 \%$ in $\mathrm{MF}$ ) showed an increasing trend along seral stages.

\section{Field data collection}

Our study area was divided into three successional stages: wet meadow with sparse Salix individuals, young forest with trees 7-10 $\mathrm{m}$ in height, and mature forest with trees $15-20 \mathrm{~m}$ in height. A total of 36 sample plots, including 10 plots in WM $(10 \mathrm{~m} \times 10 \mathrm{~m}), 16$ in YF $(5 \mathrm{~m} \times 5 \mathrm{~m})$, and 10 in $\mathrm{MF}(10 \mathrm{~m} \times 10 \mathrm{~m})$, were established in February 2006. Sample plots were randomly chosen in the center of each seral stage.

In each plot, all woody stems were identified by species. Basal area (at $0.3 \mathrm{~m}$ height) and density of each woody species were also determined. The age of each woody stem was estimated by counting tree rings from increment cores for the stems $\geq 2 \mathrm{~m}$ height and cut-discs for the stems $<2 \mathrm{~m}$ at ground level. Canopy closure (\%) was estimated with a densitometer at the center of three randomly chosen plots for each successional stage. All vascular herbaceous plants were identified by species in a subplot $(1 \mathrm{~m} \times 1 \mathrm{~m})$ located in the center of each plot. Herbaceous vegetation cover was estimated with a point contact frame. All identified plant species were classified into plant functional types, following (Ryang et al. 2004). Nomenclature followed Lee (1985), Park (1995), and the Korean Plant Names Index (n.d.).

\section{Soil samples}

Soil samples were collected in March 2006, immediately after snowmelt. For this sampling, five plots were 
selected randomly for each successional stage (WM, YF, and MF). Soil samples were collected from five subplots $(1 \mathrm{~m} \times 1 \mathrm{~m})$. Each soil sample was a pool of 10 random cores with a combined volume of $157 \mathrm{~cm}^{3}$ to the $8-\mathrm{cm}$ depth after removal of the litter and humus layers. This process yielded a total of 75 samples, 25 for each successional stage. The soil samples were spread thinly on a mixture of vermiculate, peat moss, and pearlite on plastic trays (length $49 \mathrm{~cm}$, width $33 \mathrm{~cm}$, and depth $8 \mathrm{~cm}$ ). The trays were placed in a mesh-screened nursery at Seoul Women's University. From May to September, emerged seedlings were identified to the species or genus and removed from the trays after their emergence was recorded. Identification of germinated seedlings was followed Lee (1985), Park (1995), and the Korean Plant Names Index (n.d.).

\section{Statistical analysis}

One-way analysis of variance (ANOVA) was used to compare the difference in seedling density and species richness among the wet meadow, young forest, and mature forest seed banks. The Tukey-Kramer procedure followed the ANOVA for post hoc comparison at $\alpha=$ 0.05 . We also tested the difference in seedling density and species richness between annuals and perennials; among wetland, ruderal, and shade-tolerant tree/shrub species; and among graminoid, forb, and woody species with ANOVA (Lang and Halpern 2007; Sokal and Rohlf 1981). Germinant density was fed into a matrix for nonparametric multidimensional scaling (NMS) ordination (Foster and Tilman 2000; McCune and Mefford 1999; McCune and Grace 2002) to examine a successional pattern of species assemblages in the seed banks. We also used multi-response permutation procedures (MRPP) to test heterogeneity in species composition of the seed banks of the wet meadow, young forest, and mature forest. MRPP is a nonparametric Monte Carlo procedure that compares the weighted average within-group similarity to the expected average. It produces $A$-statistics (the chance-corrected within-group agreement) with a probability of statistical significance (McCune and Grace 2002).

Indicator species for each successional stage were identified by indicator species analysis (ISPAN) (McCune and Mefford 1999; Dufrêne and Legendre 1997). Similarity between the ground vegetation and soil seed bank was examined using Sørensen's index (Mueller-Dombois and Ellenberg 1974). SPSS ver. 12.0 (SPSS Inc 2003) and PC-ORD ver. 4.0 (McCune and Mefford 1999) were applied to univariate and multivariate analyses, respectively.

\section{Abbreviations}

GFBR: Gwangneung Forest Biosphere Reserve; MF: Mature forest; WM: Wet meadow; YF: Young forest

\section{Acknowledgements}

We thank Professor Young D. Choi at Purdue University for helpful comments on the early version of this manuscript.

\section{Funding}

This study was supported by Korea National Arboretum (KNA) (Grant no. KNA1-2-17, 13-3) in Republic of Korea.

\section{Availability of data and materials}

The datasets generated during and/or analyzed during the current study are available from the corresponding author on reasonable request.

\section{Authors' contributions}

CYC, LSM, and LCS designed the study. CYC, KBY, and LSM collected and analyzed the data. CYC wrote the initial draft of the manuscript. All authors read and approved the final manuscript.

Ethics approval and consent to participate

Not applicable.

Consent for publication

Not applicable.

\section{Competing interests}

The authors declare that they have no competing interests.

\section{Publisher's Note}

Springer Nature remains neutral with regard to jurisdictional claims in published maps and institutional affiliations.

\section{Author details}

${ }^{1}$ Plant Conservation Division, Korea National Arboretum, Pocheon 11186 South Korea. ${ }^{2}$ Division of Ecological Assessment Research, National Institute of Ecology, Seocheon 33657, South Korea. ${ }^{3}$ Faculty of Environment and Life Sciences, Seoul Women's University, Seoul 01797, South Korea.

Received: 10 May 2018 Accepted: 20 June 2018

Published online: 03 July 2018

\section{References}

Bossuyt, B., \& Hermy, M. (2001). Influence of land use history on seed banks in European temperate forest ecosystems: a review. Ecography, 24, 225-238.

Byun, C. H., Kwon, G. J., Lee, D. W., Wojdak, J. M., \& Kim, J. G. (2008). Ecological assessment of plant succession and water quality in abandoned rice fields. Journal of Ecology and Environment, 31, 213-223.

Chambers, J. C. (2000). Seed movements and seedling fates in disturbed sagebrush steppe ecosystems: implications for restoration. Ecological Applications, 10, 1400-1413.

Chambers JC, \& JA, M. M. (1994). A day in the life of a seed: movements and fates of seeds and their implications for natural and managed systems. Annual Review of Ecology and Systematics, 25, 263-292.

Cho, Y. C., Kim, K. S., Pi, J. H., \& Lee, C. S. (2016). Restoration effects influenced by plant species and landscape context in Young-il region, Southeast Korea: structural and compositional assessment on restored forest. Journal of Ecology and Environmental, 39, 1-10.

Cho, Y. C., Shin, H. C., Kim, S. S., \& Lee, C. S. (2007). Dynamics and conservation of the Gwangneung national forest in central Korea: a national model for forest restoration. Journal of Plant Biology, 50, 615-625.

Comín, F. A., Romero, J. A., Hernández, O., \& Menéndez, M. (2001). Restoration of wetlands from abandoned rice fields for nutrient removal, and biological community and landscape diversity. Restoration Ecology, 9, 201-208.

De Andrade, L. A. Z., \& Miranda, H. S. (2014). The dynamics of the soil seed bank after a fire event in a woody savanna in central Brazil. Plant Ecology, 215, 1199-1209.

Dufrêne, M., \& Legendre, P. (1997). Species assemblages and indicator species: the need for a flexible asymmetrical approach. Ecological Monographs, 67, $345-366$.

Falińska, K. (1999). Seed bank dynamics in abandoned meadows during a 20-year period in the Białowieża National Park. Journal of Ecology, 87, 461-475.

FAO. (2015). Statistical pocketbook. World food and agriculture. Rome: FAO. 
Foster, B. L., \& Tilman, D. (2000). Dynamic and static views of succession: testing the descriptive power of the chronosequence approach. Plant Ecology, 146, 1-10.

Fujioka, M., Armacost Jr., J. W., Yoshida, H., \& Maeda, T. (2001). Value of fallow farmlands as summer habitats for waterbirds in a Japanese rural area. Ecological Research, 16, 555-567.

Halpern, C. B., Evans, S. A., \& Nielson, S. (1999). Soil seed banks in young, closed-canopy forests of the Olympic Peninsula, Washington: potential contributions to understory reinitiation. Canadian Journal of Botany, 77 992-935.

Harwell, M. C., \& Havens, K. E. (2003). Experimental studies on the recovery potential of submerged aquatic vegetation after flooding and desiccation in a large subtropical lake. Aquatic Botany, 77, 131-151.

Hopfensperger, K. N. (2007). A review of similarity between seed bank and standing vegetation across ecosystems. Oikos, 116, 1438-1448.

Keddy, P. A., Wisheu, I. C., Shipley, B., \& Gaudet, C. (1989). Seed banks and vegetation management for conservation: toward predictive community ecology. In M. A. Leck, V. T. Parker, \& R. L. Simpson (Eds.), Ecology of soil seed banks (pp. 347-363). San Diego: Academic Press.

Kim, D. J. (2017). Ecology and environment of Chosun dynasty. Seoul: Pureunryeoksa (Blue History Pub) (in Korean, title is not official translation).

Kim, J. H., Nam, J. M., \& Kim, J. G. (2016). Effects of nutrient availability on the amphicarpic traits of Persicaria thunbergii. Aquatic Botany, 131, $45-50$.

Korean Plant Names Index. Korea National Arboretum, Pocheon. http://www. nature.go.kr/main/Main.do. Accessed 10 Jul 2017.

Kurechi, M. (2007). Restoring rice paddy wetland environments and the local sustainable society_-Project for achieving co-existence of rice paddy agricultural with waterbirds at Kabukuri-numa, Miyagi Prefecture, Japan. Global Environmental Research, 11, 141-152.

Lang, N. L., \& Halpern, C. B. (2007). The soil seed bank of a montane meadow: consequences of conifer encroachment and implications for restoration. Canadian Journal of Botany, 85, 557-569.

Lee, C. S., You, Y. H., \& Robinson, G. R. (2002). Secondary succession and natural habitat restoration in abandoned rice fields of central Korea. Restoration Ecology, 10, 306-314.

Lee, S. M., Cho, Y. C., Shin, H. C., Oh, W. S., Seol, E. S., Park, S. A., \& Lee, C. S. (2008). Successional changes in seed banks in abandoned rice fields in Gwangneung, central Korea. Journal of Ecology and Field Biology, 31, 269-276.

Lee, T. B. (1985). Illustrated Flora of Korea. Seoul: Hyangmoonsa (in Korean).

Leicht-Young, S. A., Pavlovic, N. B., Grundel, R., \& Frohnapple, K. J. (2009). A comparison of seed banks across a sand dune successional gradient at Lake Michigan dunes (Indiana, USA). Plant Ecology, 202, 299-308.

Li, E. H., Liu, G. H., Li, W., Yuan, L. Y., \& Li, S. C. (2008). The seed-bank of a lakeshore wetland in Lake Honghu: implications for restoration. Plant Ecology, 195, 69-76.

Lim, J. W., Shin, J. H., Jin, G. Z., Chun, J. H., \& Oh, J. S. (2003). Forest structure, site characteristics and carbon budget of the Gwangneung natural forest in Korea. Korean Journal of Agricultural and Forest Meteorology, 5, 101-109.

Looney, P. B., \& Gibson, D. J. (1995). The relationship between the soil seed bank and above-ground vegetation of a coastal barrier island. Journal of Vegetation Science, 6, 825-836.

López-Mariño, A., Luis-Calabuig, E., Fillat, F., \& Bermúdez, F. F. (2000). Floristic composition of established vegetation and the soil seed bank in pasture communities under different traditional management regimes. Agriculture, Ecosystems and Environment, 78, 273-282.

Ma, M., Zhou, X., \& Du, G. (2011). Soil seed bank dynamics in alpine wetlands succession on the Tibetan Plateau. Plant and Soil, 346, 19-28.

Ma, M., Zhou, X., Qi, W., Liu, K., Jia, P., \& Du, G. (2013). Seasonal dynamics of the plant community and soil seed bank along a successional gradient in a subalpine meadow on the Tibetan plateau. PLoS One, 8, e80220.

McCune, B., \& Grace, J. B. (2002). Analysis of ecological communities. Oregon: MjM Software Design.

McCune, B., \& Mefford, M. J. (1999). PC-ORD. Version 4.0. Multivariate analysis of ecological data. Oregon: MjM Software Design.

Ministry of Agriculture and Forestry. (2006). Agriculture and forestry statistical yearbook. Gwacheon: Ministry of Agriculture and Forestry.

Moore, H. I., \& Burr, S. (1948). The control of rushes on newly reseeded land in Yorkshire. Journal of the British Grassland Society, 3, 283.

Mueller-Dombois, D., \& Ellenberg, H. (1974). Aims and methods of vegetation ecology. New York: Wiley.
Olano, J. M., Caballero, I., Laskurain, N. A., Loidi, J., \& Escudero, A. (2002). Seed bank spatial pattern in a temperate secondary forest. Journal of Vegetation Science, 13, 775-784.

Park, S. H. (1995). Colored illustrations of naturalized plants of Korea. Seoul: Ilchokak press (in Korean).

Pickett, S. T. A., \& McDonnell, M. J. (1989). Seed dynamics in temperate deciduous forest. In M. A. Leck, V. T. Parker, \& R. L. Simpson (Eds.), Ecology of soil seed banks (pp. 123-145). San Diego: Academic Press.

Plue, J., Van Gils, B., Peppler-Lisbach, C., De Schrijver, A., Verheyen, K., \& Hermy, M. (2010). Seed-bank convergence under different tree species during forest development. Perspectives in Plant Ecology, Evolution and Systematics, 12, 211-218.

Prach, K. (2003). Spontaneous succession in Central-European man-made habitats: what information can be used in restoration practices? Applied Vegetation Science, 6, 125-129.

Rhee, S. Y., Kang, H. K., \& Lee, S. (2009). The abandoned farmlands status and management in rural area. Journal of Korean Society of Rural Planning, 15, 15-29 (in Korean with English abstract).

Richards, P. W., \& Clapham, A. R. (1941). Juncus effusus L. (Juncus communis $\beta$ effusus E. Mey). Journal of Ecology, 19, 375-380.

Richter, R., \& Stromberg, J. C. (2005). Soil seed banks of two montane riparian areas: implications for restoration. Biodiversity and Conservation, 14, 993-1016.

Ryang, H. S., Kim, D. S., \& Park, S. H. (2004). Weeds of Korea. Seoul: Rijeon Agricultural Resources Publications; . (in Korean).

Savadogo, P., Sanou, L., Dayamba, S. D., Bognounou, F., \& Thiombiano, A. (2017). Relationships between soil seed banks and above-ground vegetation along a disturbance gradient in the W National Park trans-boundary biosphere reserve, West Africa. Journal of Plant Ecology, 10, 349-363.

Schmidt, I., Leuschner, C., Molder, A., \& Schmidt, W. (2009). Structure and composition of the seed bank in monospecific and tree species-rich temperate broad-leaved forests. Forest Ecology and Management, 257, 695-702.

Sokal, R. R., \& Rohlf, F. J. (1981). Biometry. San Francisco: WH Freeman.

SPSS Inc. SPSS 12.0 for windows. 2003

Thompson, K. (2000). The functional ecology of soil seed banks. In M. Fenner (Ed. ), Seeds: The ecology of regeneration in plant communities (pp. 231-258). Wallingford: CAB International.

Thompson, K., \& Grime, J. P. (1979). Seasonal variation in the seed banks of herbaceous species in ten contrasting habitats. Journal of Ecology, 67, 893921.

van der Valk, A. B. (1981). Succession in wetlands: a Gleasonian approach. Ecology. ,62, 688-696.

Yamada, S., Kitagawa, Y., \& Okubo, S. (2013). A comparative study of the seed banks of abandoned paddy fields along a chronosequence in Japan. Agriculture, Ecosystems \& Environment, 176, 70-78.

Yamada, S., Okubo, S., Kitagawa, Y., \& Takeuchi, K. (2002). Extensive cultivation management in wet-follow paddy fields on the Tama Hills. Journal of the Japanese Institute of Landscape Architecture, 65, 290-293 (in Japanese with English abstract).

Yamada, S., Okubo, S., Kitagawa, Y., \& Takeuchi, K. (2007). Restoration of weed communities in abandoned rice paddy fields in the Tama Hills, central Japan. Agriculture, Ecosystems \& Environment, 119, 88-102.

Yang, D., \& Li, W. (2013). Soil seed bank and aboveground vegetation along a successional gradient on the shores of an oxbow. Aquatic Botany, 110, 67-77.

Yoon, J. Y., Kim, H., Nam, J. M., \& Kim, J. G. (2011). Optimal environmental range for Juncus effusus, an important species in an endangered insect species (Nannopya pygmaea) habitat in Korea. Journal of Ecology and Field Biology, 34, 223-235

Zabinski, C. A., Wojtowicz, T., \& Cole, D. N. (2000). The effect of recreation disturbance on subalpine seed banks in the Rocky Mountains of Montana. Canadian Journal of Botany, 78, 577-582. 